\title{
Aktivitas Antitumor Ekstrak Etanol Daun Keladi Tikus (Typhonium flagelliforme) secara In Vivo pada Mencit
}

\author{
(IN VIVO ANTITUMOR ACTIVITY OF TYPHONIUM FLAGELLIFORME-LEAVES- \\ ETHANOL EXTRACT-AGAINST TUMORS DISORDERS IN MICE)
}

\author{
Ardi Sandriya ${ }^{1}$, Bambang Pontjo Priosoeryanto ${ }^{2,6^{*}}$, \\ Gunanti $^{3}$, Eva Harlina ${ }^{2}$, Riski Rostantinata ${ }^{2}$, \\ Lina Noviyanti Sutardi ${ }^{4}$, Rachmi Ridho $^{5}$ \\ ${ }^{1}$ Program Studi Biomedis Hewan, Sekolah Pascasarjana, \\ ${ }^{2}$ Divisi Patologi, ${ }^{3}$ Divisi Bedah dan Radiologi, ${ }^{4}$ Divisi Farmasi, \\ Departemen Klinik, Reproduksi dan Patologi, \\ Fakultas Kedokteran Hewan, Institut Pertanian Bogor \\ Jl. Agatis Kampus IPB Dramaga Bogor, 16680 Indonesia, \\ ${ }^{5}$ Fakultas Farmasi, Universitas Gunadarma, Depok, \\ ${ }^{6}$ Pusat Studi Biofarmaka Tropika, Institut Pertanian Bogor \\ Email: bpontjo4@gmail.com
}

\begin{abstract}
ABSTRAK
Penelitian ini bertujuan untuk mempelajari efektivitas ekstrak etanol daun keladi tikus (Typhonium flagelliforme) untuk terapi penyakit tumor. Penelitian ini menggunakan enam 6 ekor mencit betina berumur lima minggu dengan bobot badan 20-25 g yang telah diinduksi karsinogen 7.12dimetilbenz( $\alpha$ )anthracne (DMBA). Mencit dibagi menjadi dua kelompok perlakuan masing-masing kelompok terdiri dari tiga ekor mencit yaitu kelompok yang diberi plasebo (KK) dan kelompok yang diberi ekstrak etanol daun keladi tikus (KE). Kelompok KK diberi plasebo berupa aquabides. Kelompok KE diberi ekstrak etanol daun keladi tikus dengan dosis $120 \mathrm{mg} / \mathrm{kg}$ BB. Pengamatan dilakukan secara makroskopik dan mikroskopik. Massa tumor dari kedua kelompok mencit dikoleksi dan difiksasi dalam neutral buffered formalin (NBF) $10 \%$. Kemudian dibuat preparat histopatologi dan diwarnai pewarna Hematoksilin-Eosin (HE). Hasil penelitian menunjukkan gambaran makroskopik permukaan kulit pada daerah tumbuhnya tumor mengalami alopesia, tumbuh benjolan berwarna kemerahan dan keropeng. Hasil pengukuran bobot badan mencit kelompok KK mengalami penurunan, sedangkan berat badan mencit pada kelompok KE mengalami kenaikan setiap minggunya. Diameter tumor kelompok KK mengalami peningkatan, sedangkan diameter tumor pada kelompok KE mengalami penurunan pada minggu ke empat pemberian bahan uji. Gambaran mikroskopik menunjukkan benjolan massa tumor yang terbentuk terdiri atas tiga jenis tumor yaitu anaplastic carcinoma (16,7\%), fibrosarcoma (16,7\%) dan squamous cell carcinoma (66,6\%). Ketiga tumor digolongkan dalam diferensiasi baik 33,4\%, diferensiasi sedang $33,4 \%$, diferensiasi buruk $16,7 \%$, dan tidak berdiferensiasi $16,7 \%$. Laju pertumbuhan tumor selaras dengan tingkat diferensiasi. Tumor yang bermetastasis sebanyak 50\% dan tidak bermetastasis sebanyak 50\%. Rataan indeks mitosis dan angiogenesis terjadi penurunan yang nyata $(p<0.05)$ pada kelompok mencit yang diberi ekstrak etanol daun keladi tikus dibandingkan kelompok kontrol. Disimpulkan bahwa ekstrak etanol daun keladi tikus menurunkan pertumbuhan tumor dan dapat digunakan untuk terapi tumor.
\end{abstract}

Kata-kata kunci: ekstrak etanol; daun keladi tikus; in vivo; mencit; tumor; Typhonium flagelliforme

\section{ABSTRACT}

The objective of this study is to determine the effectiveness of the etanol extract of Typhonium flagelliforme leaves against tumor disorders. Six female mice of DDY strain at 5 weeks of age with 20-25 $\mathrm{g}$ of body weight were used in this study. Mice were induced by carcinogens 7.12-dimetilbenz $(\alpha)$ anthracene (DMBA). Mice were divided into two groups with three mice of each group, placebo group (KK) and $T$. flagelliforme leaves ethanol extract group (KE). The placebo group was given the aquabidest. The etanol 
extract of Typhonium flagelliforme leaves group was given the extract at dose $120 \mathrm{mg} / \mathrm{kg}$ of BW. The development of tumor masses was observed by gross and microscopical assays. Treated-tumors masses were collected and fixed in 10\% neutral buffered formalin (NBF). Histopathological sections were stained with Hematoxylin-Eosin (HE). The results showed the gross lesions of the skin surface in the tumor area were alopecia, reddish, and crusting. The results of measuring the bodyweight of mice in the KK group decreased, while the bodyweight of mice in the KE group increased every week. The tumor diameter in the KK group increased, while the tumor diameter in the KE group decreased at week four of the treatment. Microscopically, the tumors were developed into 3 types of tumors namely anaplastic carcinoma (16.7\%) fibrosarcoma (16.7\%), and squamous cell carcinoma (66.6\%). The three tumors were classified as well as differentiation $33.4 \%$, moderate differentiation $33.4 \%$, poorly differentiation $16.7 \%$, and undifferentiation $16.7 \%$. The tumor growth rate is in accordance to the differentiation level. Tumors that metastasis $50 \%$ and did not metastasis 50\%. The results of mitosis index and angiogenesis were significantly decreased $(p<0.05)$ in treatment groups compared to the control group. It was concluded that the T. flagelliforme leaves-etanol extract decreases tumor growth and it seems can be used for tumor therapy.

Keywords: etanol extract; Typhonium flagelliforme; in vivo; mice; tumor.

\section{PENDAHULUAN}

Tumor merupakan gangguan pertumbuhan yang ditandai dengan adanya proliferasi atau perbanyakan sel yang berlebih, abnormal dan tidak terkontrol. Sel tumor mengalami perubahan atau transformasi pada satu atau lebih titik utama pertumbuhan, dan umumnya diikuti dengan proses penyebaran ke bagian tubuh lainnya (Priosoeryanto, 2014). Tumor merupakan salah satu penyakit yang dapat menyerang manusia dan hewan.

Tingkat kejadian dan kematian akibat tumor pada manusia tergolong tinggi. Total kejadian tumor di Tiongkok mencapai 666/ 100.000 orang pada daerah perkotaan, sedangkan pada daerah pedesaan berkisar 440/ 100.000 orang (Zheng et al., 2016). Tercatat kasus tumor sebanyak 269/100.000 orang di Korea pada tahun 2016 (Jung et al., 2019). Di Indonesia kejadian tumor sebesar 1,4/1.000 orang (Hasanah dan Widowati, 2016). Menurut World Health Organisation (WHO) kematian akibat kanker lebih tinggi dibandingkan dengan kematian akibat Acquired Immune Deficiency Syndrome (AIDS), tuberkulosis maupun malaria (Rachmawati, 2020).

Tumor merupakan salah satu penyakit yang sering diderita oleh hewan. Menurut Gupta et al. (2012), di dunia terdapat lebih dari 30.000 anjing dan kucing yang menderita spontaneous neoplasma. Kejadian tumor di California, Amerika Serikat pada semua regio anatomi pada anjing adalah 381/100.000 dan pada kucing 155.8/100.000 (Baioni et al., 2017). Tercatat kasus tumor sebanyak 282/100.000 pada anjing dan 77/100.000 pada kucing di Italia bagian utara (Cerbo et al., 2014).

Tumor memiliki beberapa faktor penting dalam perkembangan di antaranya angiogenesis (Exertier et al., 2013) dan mitosis (Funk et al., 2016). Angiogenesis adalah proses pembentukan pembuluh darah baru, pembuluh darah berfungsi sebagai pemasok nutrisi dan oksigen untuk perkembangan tumor (Kim dan Ma, 2019). Indeks mitosis merupakan salah satu parameter keganasan tumor. Mitosis adalah proses pembelahan satu sel menjadi dua sel baru (Singh et al., 2019).

Pengobatan tumor secara konvensional dilakukan dengan cara operasi, kemoterapi, radioterapi, dan lain sebagainya. Pengobatan cara ini tidak dapat membunuh sel tumor secara selektif dan dapat menimbulkan beberapa efek samping yang tidak diinginkan. Pengobatan alternatif untuk penyakit tumor sudah banyak dikembangkan. Pengobatan alternatif yang banyak dikembangkan yaitu obat herbal.

Indonesia memiliki biodiversitas terbesar ke dua di dunia, sehingga Indonesia disebut juga sebagai megabiodiversitas dalam keragaman flora dan fauna (Wulandari et al., 2018). Biodiversitas yang besar ini merupakan faktor penting dalam perkembangan pengobatan tradisional Indonesia (Rintelen et al., 2017). Tanaman obat adalah tanaman yang diketahui atau dipercaya memiliki berbagai manfaat seperti mengurangi rasa nyerisakit, meningkatkan daya tahan tubuh, membunuh bibit penyakit, memperbaiki organ yang rusak serta menghambat tumor (Slamet dan Andarias, 2018). Penggunaan tanaman obat telah dikembangkan menjadi beberapa produk yaitu jamu, produk obat herbal terstandar, kosmetik, suplemen makanan, dan produk industri lainnya (Nugroho, 2017).

Penggunaan produk obat herbal diketahui memiliki potensi sebagai penghambat 
perkembangan tumor. Salah satu tanaman yang memiliki potensi sebagai antitumor adalah keladi tikus (Typhonium flagelliforme). Senyawa yang berkhasiat pada tanaman keladi tikus adalah flavonoid (Wimpy dan Harningsih 2017), alkaloid, saponin, steroid, terpenoid dan glikosida (Sianipar et al. 2016). Senyawa golongan flavonoid, alkanoid, dan terpenoid mempunyai aktivitas antikanker (Puspitasari et al., 2015). Ekstrak keladi tikus juga mengandung protein inaktivasi ribosom (RIP) (Syafruddin et al., 2018). Protein ini dapat memotong DNA sel kanker atau RNA, sehingga dapat merusak kanker tanpa mengganggu jaringan di sekitarnya (Purwaningsih et al., 2014). Menurut Sukardi (2011), senyawa antioksidan yang terkandung dalam keladi tikus berpotensi mengurangi perkembangan tumor. Hasil penelitian melaporkan bahwa ekstrak keladi tikus dapat menghambat pertumbuhan kanker prostat dan kanker payudara (Farida et $a l ., 2010)$. Saat ini belum diketahui tingkat efektivitas penggunaan ekstrak etanol daun keladi tikus untuk pengobatan tumor yang diberikan secara intratumoral secara in vivo. Penelitian ini dilakukan bertujuan untuk mempelajari efektivitas penggunaan ekstrak etanol daun keladi tikus yang diberikan secara intratumoral sebagai pengobatan tumor.

\section{METODE PENELITIAN}

Penelitian ini telah disetujui oleh Komisi Etik Hewan Fakultas Kedokteran Hewan Institut Pertanian Bogor dengan nomor 153/ KEH/SKE/X/2019.

\section{Ekstrak Etanol Daun Keladi Tikus}

Ekstrak etanol daun keladi tikus yang digunakan pada penelitian ini diperoleh dari penelitian sebelumnya yang dilakukan oleh Priosoeryanto et al. (2020). Ekstraksi dilakukan dengan metode maserasi yaitu perendaman serbuk simplisia sebanyak 250 gram dalam cairan penyari etanol 70-\% dengan perbandingan 1:10. Perendaman dilakukan selama satu kali 24 jam, kemudian disaring dan ekstrak cair disimpan dalam wadah tertutup. Ampas yang diperoleh direndam kembali dalam cairan penyari etanol 70-\% dengan perbandingan 1:10 dan disaring setelah 24 jam. Seluruh ekstrak cair yang diperoleh kemudian dipekatkan dengan evaporator pada suhu $40^{\circ} \mathrm{C}$ agar dihasilkan ekstrak kental.

\section{Hewan Coba}

Penelitian ini menggunakan enam ekor hewan coba mencit betina galur DDY yang berumur lima minggu, dengan bobot badan 2025 g (Adnyana et al., 2011). Mencit diaklimatisasi selama dua minggu, diberi pakan sebanyak dua kali sehari dan air minum secara ad libitum. Mencit dipelihara di dalam wadah plastik ukuran 35x20x15 cm berpenutup kawat, dan masing-masing wadah berisi tiga ekor mencit. Mencit dipelihara dalam satu ruangan yang dilengkapi dengan pendingin ruangan di Unit Hewan Laboratorium, Rumah Sakit Hewan Pendidikan, Institut Pertanian Bogor.

\section{Induksi Tumor}

Induksi tumor pada mencit dilakukan menurut metode Muti'ah et al. (2016) dengan pemberian 7.12-dimetilbenz( $\alpha$ )anthracene (DMBA) dosis $25 \mu \mathrm{g} / 0,005 \mathrm{~mL} / \mathrm{ekor}$. Senyawa DMBA dilarutkan dalam pelarut aseton hingga mencapai dosis yang diinginkan dan diinduksikan sebanyak dua kali seminggu secara subkutan pada bagian punggung mencit dan dilakukan selama empat minggu. Daerah yang akan diinduksi dicukur dan ditandai terlebih dahulu. Induksi diawali dengan pengolesan alkohol $70 \%$. Proses induksi dilakukan selama empat minggu, setelah proses induksi mencit diamati sampai terbentuknya massa tumor. Massa tumor terbentuk pada minggu ke-13. Kategori tumor yang digunakan untuk diterapi adalah massa tumor dengan nodul yang dapat teraba dan terlihat kasat mata.

\section{Terapi Tumor}

Terapi dilaksanakan pada akhir minggu ke14 setelah massa tumor terbentuk. Minggu ke14 dihitung sebagai minggu ke-0 sebelum dilakukannya terapi. Mencit dengan massa tumor hasil induksi dibagi ke dalam dua kelompok, yaitu kelompok kontrol yang diberi plasebo berupa aquabides (KK) dan kelompok yang diberi ekstrak etanol daun keladi tikus (KE). Ekstrak etanol daun keladi tikus diberikan dengan dosis $120 \mathrm{mg} / \mathrm{kg}$ BB (Priosoeryanto et al., 2020). Ekstrak dan plasebo diberikan dengan volume yang sama yaitu $0,05 \mathrm{~mL}$. Massa tumor disuntik dengan ekstrak etanol daun keladi tikus secara intratumoral. Penyuntikan dilakukan tiga hari berturut-turut per minggu dan dilaksanakan selama empat minggu (Hampel et al., 2007). Pada tahap ini pengamatan makroskopis mulai dilaksanakan. 


\section{Pengamatan Makroskopis.}

Gambaran makroskopis tumor yang diperiksa meliputi kelainan kulit dan rambut (alopecia, luka, keropeng, dan warna massa tumor), yang diamati dengan cara melihat bagian tumor dan bagian sekitar tumor; diameter tumor yang diukur menggunakan jangka sorong (pengukuran dilakukan setiap minggu pada bagian vertikal dan horizontal); bentuk massa tumor (bulat atau seperti bunga kol atau lainnya); bobot badan mencit (ditimbang setiap minggu menggunakan timbangan digital); dan pengamatan keberadaan massa tumor di bagian tubuh lainnya. Pengambilan data dilakukan dari hari ke-1 sebelum terapi sampai hari ke-7 pascaterapi.

\section{Terminasi Hewan Coba}

Setelah masa terapi dan pengamatan selesai, semua mencit dikorbankan nyawanya dengan cara dieuthanasi menggunakan dosis lethal anesthesi (dosis tiga kali lebih tinggi dari dosis anesthesi). Anestetikum yang digunakan adalah kombinasi Ketamin dosis $300 \mathrm{mg} / \mathrm{kg}$ BB dan Xylazine dosis 15-30 mg/kg BB (AVMA, 2013).

\section{Pengambilan Sampel dan Pembuatan Sediaan Histopatologi}

Setelah dikorbankan nyawanya seluruh mencit dinekropsi dan dilakukan pengambilan massa tumor. Seluruh jaringan tumor difiksasi dalam neutral buffered formalin (NBF) $10 \%$, setelah jaringan matang kemudian dipotong dengan ketebalan $0,5 \mathrm{~cm}$, ditempatkan dalam tissue cassette dan dimasukkan ke dalam tissue processor. Selama dalam tissue processor terjadi proses dehidrasi dan clearing. Sampel jaringan selanjutnya dibenamkan dalam parafin cair kemudian didinginkan. Blok paraffin yang sudah dingin dipotong menggunakan microtome dengan ketebalan $\pm 4-5$ mikron. Proses terakhir adalah pewarnaan dengan Hematoksilin-Eosin (HE) (Cardiff et al., 2014).

\section{Pengamatan Mikroskopis}

Gambaran mikroskopis yang diamati adalah struktur sel tumor, diferensiasi tumor, laju pertumbuhan, metastasis, indeks mitosis dan angiogenesis. Menurut Singh (2014), derajat diferensiasi tumor digolongkan menjadi (a) diferensiasi baik, jika sel yang terbentuk menyerupai sel asal yang tampak jelas, jembatan antar sel tampak jelas, mitosis lambat dan tidak mengalami metastasis; (b) diferensiasi sedang, jika bentuk sel kurang jelas, tersusun tidak beraturan, laju pertumbuhan relatif lebih cepat, jembatan antar sel yang tidak menonjol, mitosis relatif banyak, ukuran dan bentuk bervariasi; (c) diferensiasi buruk, jika tidak menunjukkan karakteristik sel tertentu atau primitif atau bentuk sel yang abnormal, tidak ada jembatan antar sel dan terjadi mitosis yang tinggi.

Pengamatan angiogenesis dilakukan dengan menghitung jumlah pembuluh darah pada lima lapang pandang mikroskop perbesaran 40x10, dilakukan sebanyak dua kali lalu dirataratakan (Ullah et al., 2013). Indeks mitosis diperoleh dengan menghitung jumlah sel yang sedang mengalami mitosis (pembelahan) pada 10 lapang pandang mikroskop dengan perbesaran 40x10 dan dirata-ratakan (Mirzaiian et al., 2020).

\section{Analisis Data}

Data kuantitatif hasil pengamatan makroskopis dianalisis dengan uji sidik ragam dan dilanjutkan dengan uji (lanjut) jarak berganda Duncan. Data kuantitatif hasil pengamatan mikroskopis dianalisis secara statistika menggunakan Independent Sample $\mathrm{t}$ test. Semua data kualitatif disajikan secara deskriptif.

\section{HASIL DAN PEMBAHASAN}

\section{Makroskopik}

Hasil pengamatan makroskopik tumor ditemukan tiga jenis tumor yang telah dikonfirmasi secara mikroskopik, yaitu fibrosarcoma, squamous cell carcinoma dan anaplastic carcinoma. Pada bagian kulit yang ditumbuhi tumor fibrosarcoma mengalami alopesia, ulcus, berbentuk massa padat, berwarna kemerahan. Bagian kulit yang mengalami squamous cell carcinoma juga mengalami alopesia, berbentuk seperti bunga kol, berwarna kemerahan disertai keropeng di bagian permukaan tumor. Secara makroskopis anaplastic carcinoma berbentuk massa padat, besar, dan bagian permukaannya mengalami nekrotik. Tampilan makroskopik tumor disajikan pada Gambar 1.

Hasil uji lanjutan Duncan untuk bobot badan mencit dan diameter tumor disajikan pada Tabel 1. Pada Tabel 1 tersaji data mulai dari minggu ke-0 sampai minggu ke-4 pascaterapi. Bobot badan mencit kelompok 

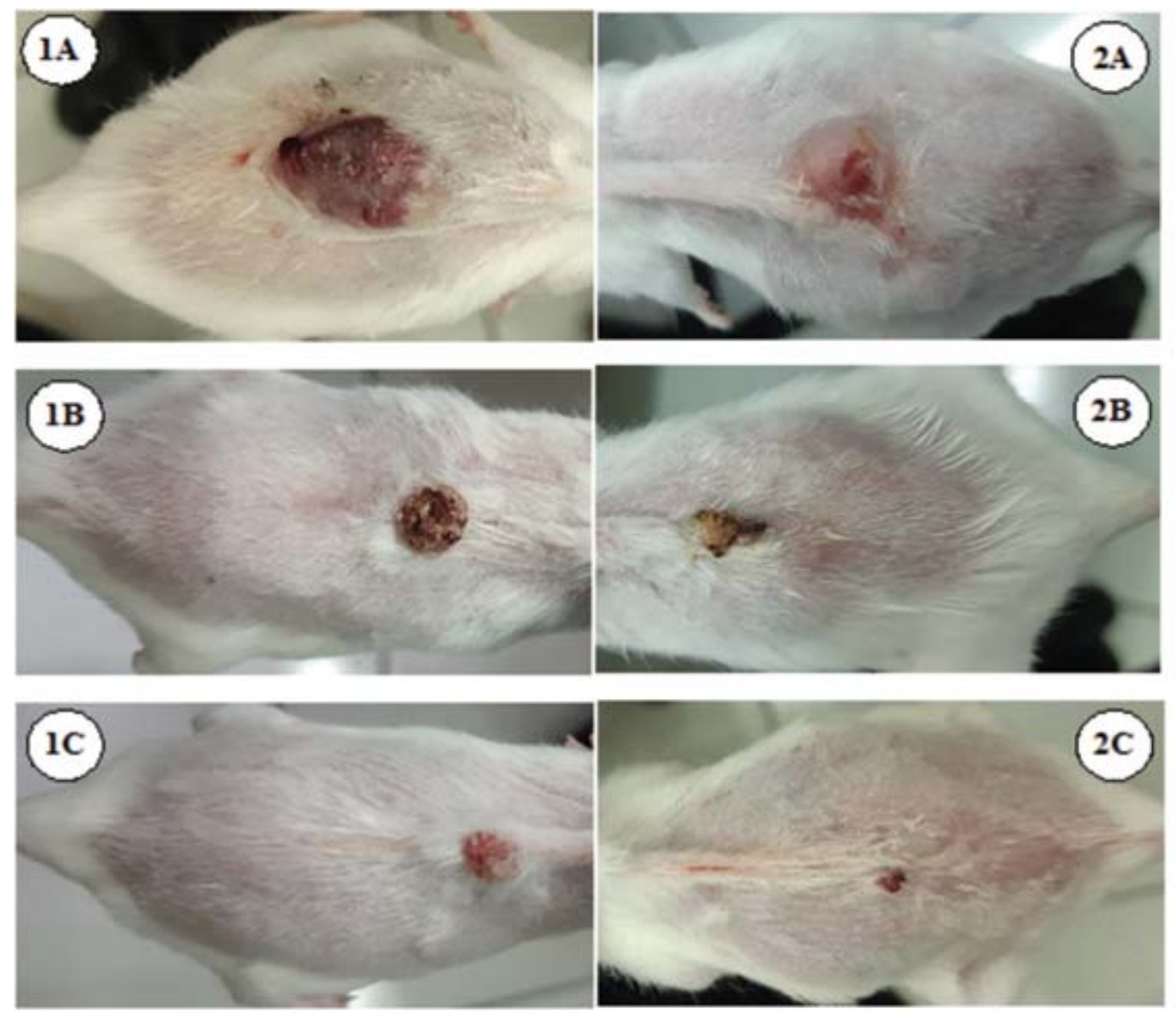

Gambar 1. Tampilan makroskopik tumor 1: Kelompok kontrol (KK); 2: Kelompok ekstrak etanol daun keladi tikus (KE); 1A: Anaplastic carcinoma, massa berwarna merah kehitaman, alopesia, dan sedikit keropeng; 1B: Squamous cell carcinoma, massa berwarna merah kehitaman, alopesia, keropeng; 1C: squamous cell carcinoma, massa berwarna merah, alopesia, sedikit keropeng; 2A: Fibrosarcoma, massa berwarna merah, alopesia, ulcus; 2B: Squamous cell carcinoma, massa berwarna kuning kehitaman, alopesia, keropeng; 2C: Squamous cell carcinoma, massa berwarna merah, alopesia, sedikit keropeng.

Tabel 1. Hasil uji Duncan ekstrak etanol daun keladi tikus terhadap bobot badan dan diameter tumor pascaterapi kelompok KK dan KE

\begin{tabular}{|c|c|c|c|c|}
\hline \multirow{2}{*}{ Waktu Pengamatan } & \multicolumn{2}{|c|}{ Bobot Badan (gram) } & \multicolumn{2}{|c|}{ Diameter Tumor (mm) } \\
\hline & KK & KK & $\mathrm{KE}$ & $\mathrm{KE}$ \\
\hline Minggu 0 & $38.3 \pm 1.5^{\mathrm{a}}$ & $0.29 \pm 0.3^{\mathrm{a}}$ & $0.36 \pm 0.3^{\mathrm{a}}$ & $31.0 \pm 2.0^{\mathrm{a}}$ \\
\hline Minggu 1 & $37.7 \pm 1.6^{\mathrm{ab}}$ & $0.42 \pm 0.4^{\mathrm{a}}$ & $0.46 \pm 0.5^{\mathrm{ab}}$ & $31.3 \pm 2.1^{\mathrm{a}}$ \\
\hline Minggu 2 & $36.7 \pm 2.3^{\mathrm{ab}}$ & $0.53 \pm 0.5^{\mathrm{ab}}$ & $0.61 \pm 0.6^{\mathrm{ab}}$ & $31.7 \pm 1.5^{\mathrm{a}}$ \\
\hline Minggu 3 & $34.8 \pm 2.0^{\mathrm{ab}}$ & $0.58 \pm 0.6^{\mathrm{ab}}$ & $0.80 \pm 0.8^{\mathrm{b}}$ & $32.3 \pm 2.1^{\mathrm{a}}$ \\
\hline Minggu 4 & $34.0 \pm 2.2^{\mathrm{b}}$ & $0.83 \pm 0.8^{b}$ & $0.72 \pm 0.7^{\mathrm{ab}}$ & $33.0 \pm 1.4^{\mathrm{a}}$ \\
\hline
\end{tabular}

Keterangan: huruf yang berbeda pada kolom yang sama menandakan perbedaan yang nyata $(p<0.05)$. 
plasebo menunjukkan perbedaan yang nyata $(p<0,05)$ di akhir pengamatan. Bobot badan mencit pada kelompok ekstrak tidak berbeda nyata $(p>0,05)$ di akhir pengamatan. Peningkatan ukuran diameter tumor pada kelompok plasebo (KK) menunjukkan perbedaan yang nyata $(p<0,05)$ pada akhir pengamatan dibandingkan minggu ke-0. Pada kelompok ekstrak, diameter tumor tidak berbeda nyata $(p>0,05)$ pada minggu ke-0 dibandingkan dengan minggu ke-4, namun diameter tumor mengalami kenaikan hingga minggu ke-3 dan mengalami penurunan di minggu ke- 4 .

Kelompok plasebo (KK) mengalami penurunan bobot badan setiap minggunya. Rataan bobot badan mencit adalah $38,3 \pm 1,5 \mathrm{~g}$ pada minggu ke- $0,37,7 \pm 1,6 \mathrm{~g}$ pada minggu ke$1,36,7 \pm 2,3$ g pada minggu ke- $2,34,8 \pm 2,0$ - g pada minggu ke-3, dan 34,0 20,2 g pada minggu ke4. Penurunan bobot badan disebabkan kondisi tubuh yang buruk akibat tumor, pengaruh stress akibat perlakuan (Halimah et al., 2017), perubahan metabolisme dan peningkatan metabolisme basal (Kusnul et al., 2019). Tumor menyebabkan gangguan penyimpanan asam amino sehingga terjadi deplesi massa otot. Perubahan metabolisme lemak terjadi akibat penurunan lipogenesis, penurunan aktivitas lipoprotein lipase (LPL) dan peningkatan lipolisis. Tumor menyebabkan produksi insulin menurun sehingga terjadi peningkatan kadar glukosa darah yang menyebabkan nafsu makan menurun (Marischa et al., 2017).

Kelompok ekstrak etanol daun keladi tikus (KE) mengalami kenaikan bobot badan secara bertahap setiap minggunya. Rataan bobot badan mencit $31,0 \pm 2,0$ g pada minggu ke- $0,31,3 \pm 2,1 \mathrm{~g}$ pada minggu ke-1, $31,7 \pm 1,5$ g pada minggu ke2, 32,3 $\pm 2,1$ g pada minggu ke- 3 , dan $33,0 \pm 1,4 \mathrm{~g}$ pada minggu ke-4. Priosoeryanto et al. (2020) menyatakan ekstrak etanol daun keladi tikus mengandung flavonoid, steroid dan tanin. Kandungan flavonoid dapat menginisiasi kestabilan berat badan (Zhang et al., 2017). Flavonoid menstimulasi penyerapan usus menjadi lebih stabil dan dapat menghambat pertumbuhan bakteri patogen di usus besar (Ahn-Jarvis et al., 2019).

Hasil pengukuran diameter tumor menunjukkan perkembangan yang berbeda pada kedua kelompok. Kelompok plasebo menunjukkan rataan diameter tumor yang terus meningkat karena tumor terus berkembang. Rataan diameter tumor $0,29 \pm 0,3 \mathrm{~cm}$ pada minggu ke-0, 0,42 $\pm 0,4 \mathrm{~cm}$ pada minggu ke- 1 ,
$0,53 \pm 0,5 \mathrm{~cm}$ pada minggu ke- $2,0,58 \pm 0,6 \mathrm{~cm}$ pada minggu ke-3, dan $0,83 \pm 0,8 \mathrm{~cm}$ pada minggu ke4. Kelompok yang diberi ekstrak etanol daun keladi tikus pada awal penelitian hingga minggu ke-3 mengalami kenaikan diameter tumor, namun pada minggu ke-4 terjadi penurunan diameter tumor. Penurunan diameter diakibatkan menyusutnya massa tumor, yang merupakan pengaruh dari terapi yang diberikan. Rataan diameter tumor $0,36 \pm 0,3 \mathrm{~cm}$ pada minggu ke-0, 0,46 $\pm 0,5 \mathrm{~cm}$ pada minggu ke- 1 , $0,61 \pm 0,6 \mathrm{~cm}$ pada minggu ke- $2,0,80 \pm 0,8 \mathrm{~cm}$ pada minggu ke-3, dan $0,72 \pm 0,7 \mathrm{~cm}$ pada minggu ke4. Ekstrak etanol daun keladi tikus memiliki efek antitumor yang baik sehingga dapat menekan pertumbuhan tumor (Purwaningsih et al. 2016).

\section{Mikroskopik}

Hasil pengamatan histologi menunjukkan terdapat tiga jenis tumor yang terbentuk yaitu anaplastic carcinoma, fibrosarcoma dan squamous cell carcinoma (Gambar 2). Persentase terjadinya anaplastic carcinoma sebesar 16,7\%, fibrosarcoma sebesar $16,7 \%$, dan squamous cell carcinoma sebesar $66,6 \%$. Sel-sel fibroblast berbentuk spindle terlihat sebagai penyusun massa tumor fibrosarcoma (Ahmed dan Sozmed, 2020), dan sel-sel epitel squamous serta mutiara tanduk (keratin pearl) pada massa tumor yang membentuk squamous cell carcinoma (Singh et al., 2019). Anaplastic carcinoma tersusun dari sel-sel yang tidak terdiferensiasi, yang membalik menjadi bentuk yang lebih primitif dan berbeda dari sel asalnya (Priosoeryanto, 2014; Oishi et al., 2017).

Diferensiasi atau grade histologi merupakan perbandingan perbedaan morfologi sel tumor dengan sel asalnya (Tyagi dan Tyagi, 2013). Diferensiasi tumor disajikan pada Gambar 3. Anaplastic carcinoma pada kelompok yang diberi plasebo termasuk ke dalam kelompok tidak berdiferensiasi, yang menunjukkan adanya pleomorfisme, sel anaplastik, dan hiperkromatik. Sel tumor fibrosarcoma pada kelompok yang diberi ekstrak berdiferensiasi buruk karena terlihat susunan sel spindle (lonjong) yang tidak teratur dengan ukuran dan bentuk sel bervariasi, serta jembatan interseluler masih terlihat jelas. Arah sel spindle yang tidak teratur merupakan salah satu indikasi terjadinya anaplastic pada tumor fibrosarcoma (Mohana et al., 2016). Dua sampel tumor squamous cell carcinoma yang masingmasing berasal dari kelompok yang diberi plasebo 

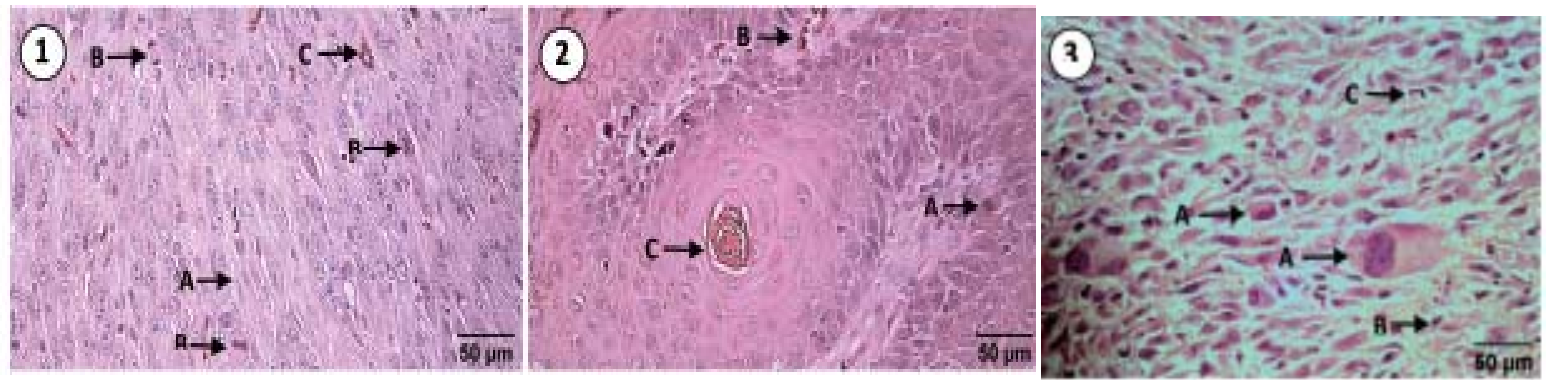

Gambar 2. Tampilan mikroskopik tumor. 1: Fibrosarcoma, A: Sel spindle; B: Mitosis; C: pembuluh darah; 2: Squamous cell carcinoma, A: Mitosis; B: pembuluh darah; C: Mutiara tanduk (keratin pearl); 3: Anaplastic carcinoma, A: Sel anaplastik; B: Mitosis; C: Pleomorfisme.
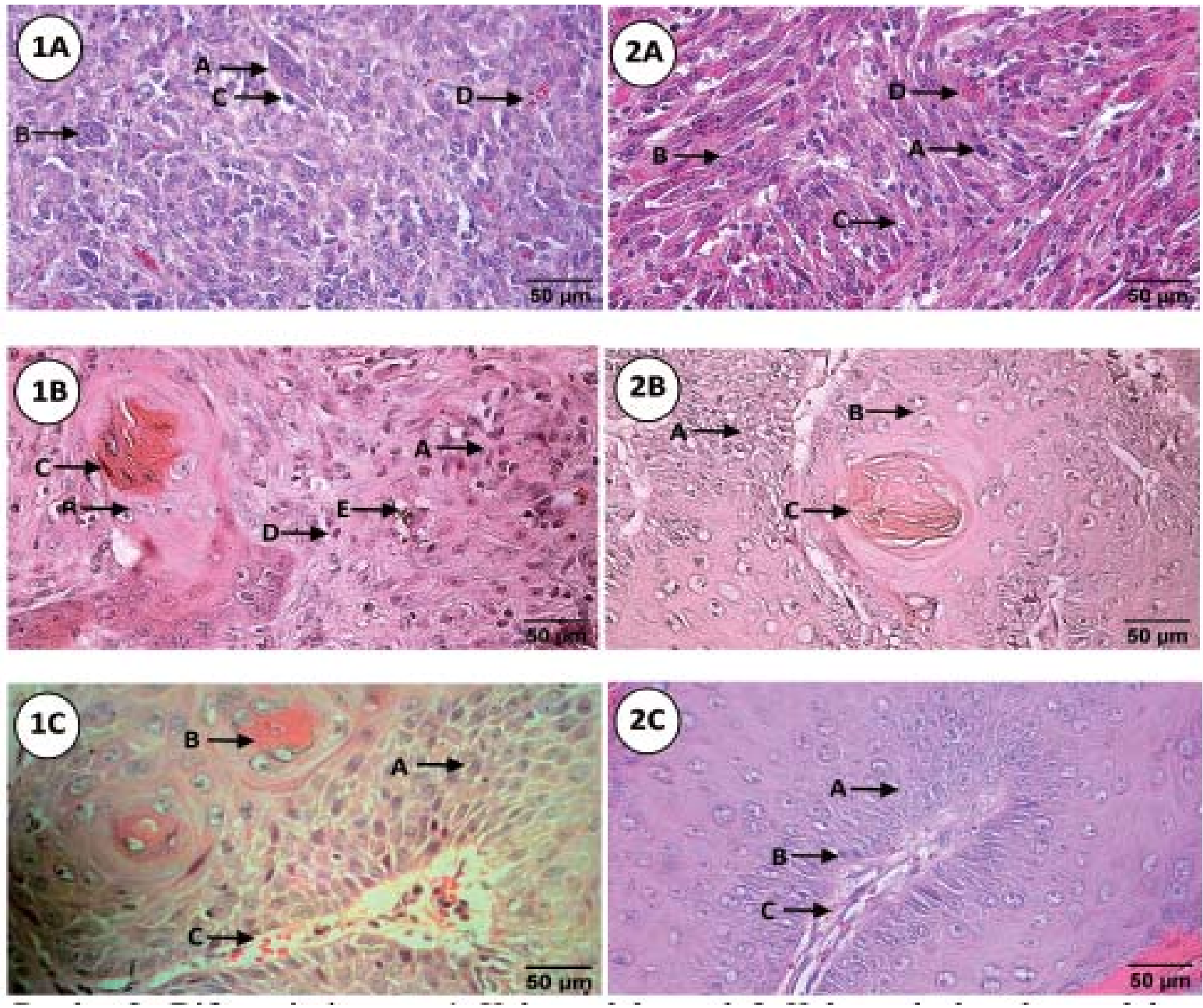

Gambar 3. Diferensiasi tumor. 1: Kelompok kontrol, 2: Kelompok ekstrak etanol daun keladi tikus. 1A: Anaplastic carcinoma (tampak sel anaplastik dengan inti dua, besar dan tidak beraturan, tidak berdeferensiasi), A: Sel anaplastik; B: Pleomorfisme; C: Hiperkromatik; D: Angiogenesis; 1B: Squamous cell carcinoma (berdiferensiasi sedang), A: Susunan sel tidak teratur; B: Jembatan interseluler; C: Mutiara tanduk; D: Eosinofil; E; Angiogenesis; 1C: Squamous cell carcinoma (berdiferensiasi baik), A: Jembatan interseluler; B: Mutiara tanduk; C: Angiogenesis; 2A: Fibrosarcoma (berdiferensiasi buruk), A: Pleomorfisme; B: Spindle ; C: Jembatan interseluler; D: Angiogenesis; 2B: Squamous cell carcinoma (berdiferensiasi sedang), A: Susunan sel tidak teratur; B: Jembatan intraseluler; C: Mutiara tanduk; 2C: Squamous cell carcinoma (berdeferensiasi baik). A: Jembatan interseluler; B: Mitosis; C: Angiogenesis. 
dan kelompok yang diberi ekstrak, termasuk ke dalam jenis berdifirensiasi sedang. Pada kedua sampel tersebut masih ditemukan mutiara tanduk yang jelas, jembatan interseluler, dan susunan sel yang tidak teratur. Terdapat dua sampel squamous cell carcinoma yang berasal dari kelompok yang diberi plasebo dan kelompok yang diberi ekstrak yang termasuk ke dalam jenis berdiferensisi baik karena memiliki mutiara tanduk, menunjukkan jembatan interseluler yang jelas, dan mitosis serta angiogenesis yang rendah. Hasil diferensiasi sel tumor disajikan pada Tabel 2.

Laju pertumbuhan tumor dapat dilihat dari hasil diferensiasi histologi (Martano et al., 2018). Semakin rendah tingkat diferensiasi maka semakin cepat sel tumor tumbuh dan menyebar (Latifah, 2017). Pemberian ekstrak etanol keladi tikus dapat memperlambat laju pertumbuhan tumor dilihat dari penghambatan penambahan diameter tumor pada pengukuran minggu ke-4 pasca-terapi (Tabel 1).

Metastasis tumor pada penelitian ini dinilai dari penyebaran sel tumor ke daerah sekitar tumor di luar situs utamanya. Metastasis biasanya juga berkaitan dengan diferensiasi sel tumor. Semakin rendah diferensiasi tumor maka semakin tinggi metastasis (Arun et al., 2015). Pada peenelitian ini tumor yang mengalami metastasis sebanyak 50\% dan tidak bermetastasis sebanyak 50\%. Dua tumor yang bermetastasis berasal dari kelompok yang diberi plasebo yaitu anaplastic carcinoma dan squamous cell carcinoma. Satu tumor bermetastasis berasal dari kelompok yang diberi ekstrak yaitu fibrosarcoma.

Pemberian bahan uji pada kelompok yang diberi ekstrak menghasilkan rataan indeks mitosis dan angiogenesis yang lebih rendah dibandingkan kelompok yang diberi plasebo. Hasil uji independent sample t test (Tabel 3) memperlihatkan adanya penurunan indeks mitosis dan angiogenesis yang nyata $(\mathrm{p}<0.05)$ pada kelompok yang diberi ekstrak etanol daun keladi tikus dibandingkan kelompok yang diberi plasebo. Kelompok yang diberi plasebo memiliki rataan nilai mitosis sebesar $4,9 \pm 0,4$, sedangkan kelompok yang diberi ekstrak memiliki rataan $3,3 \pm 0,6$. Nilai rataan angiogenesis pada kelompok yang diberi plasebo $4,7 \pm 0,3$, sedangkan pada kelompok yang diberi ekstrak adalah $3,1 \pm 0,5$. Penurunan indeks mitosis dan angiogenesis dipengaruhi oleh pemberian ekstrak etanol daun keladi tikus.

Mitosis adalah proses aktif dari proliferasi sel yang menghasilkan sel baru (Chan et al., 2012). Kecepatan proliferasi merupakan biomarker yang penting dalam pertumbuhan tumor (Veta et al., 2016). Menurut Sianipar et al. (2015), mekanisme penghambatan aktivitas pertumbuhan (antiproliferasi) sel kanker oleh ekstrak etanol daun keladi tikus karena bahan aktifnya yang dapat menginduksi proses apoptosis (kematian sel yang terprogram).

Tabel 2. Jenis diferensiasi tumor pada mencit kelompok KK dan KE

\begin{tabular}{lcccc}
\hline \multirow{2}{*}{ Jenis Diferensiasi } & \multirow{2}{*}{ Kategori } & \multicolumn{2}{c}{ Frekuensi (n) } & \\
\cline { 3 - 4 } & & KK & KE & Persentase (\%) \\
\hline Diferensiasi baik & I & 1 & 1 & \\
Diferensiasi sedang & II & 1 & 1 & 33.4 \\
Diferensiasi buruk & III & 0 & 1 & 33.4 \\
Tidak berdiferensiasi & & 1 & 0 & 16.7 \\
Total & & & & 16.7 \\
\hline
\end{tabular}

Tabel 3. Hasil uji independent sample t test ekstrak etanol daun keladi tikus terhadap indeks mitosis dan angiogenesis pada mencit kelompok KK dan KE

\begin{tabular}{lcc}
\hline Kelompok & Indeks Mitosis & Angiogenesis \\
\hline Kontrol/KK & $4.9 \pm 0.4^{\mathrm{a}}$ & $4.7 \pm 0.3^{\mathrm{a}}$ \\
Ekstrak/KE & $3.3 \pm 0.6^{\mathrm{b}}$ & $3.1 \pm 0.5^{\mathrm{b}}$ \\
\hline
\end{tabular}

Keterangan: Huruf yang berbeda pada kolom yang sama menandakan perbedaan signifikan $(\mathrm{p}<0.05)$. 
Ekstrak etanol daun keladi tikus mengandung senyawa aktif isovitexin, yang merupakan turunan flovonoid yang bersifat sebagai antitumor (Setiawati, 2016). Sampai saat ini diketahui senyawa isovitexin dan vitexin memiliki efek farmakologis yang sama, karena isovitexin adalah isomer dari vitexin (He et al., 2016). Proses apoptosis terjadi akibat penurunan potensial membran mitokondria, menurunnya kadar Bcl-2, Bcl-XL, dan Mcl-1 yang merupakan protein antiapoptosis (Priosoeryanto et al., 2020), dan meningkatnya ekspresi caspase 9 dan caspase 3 (Czemplik et al., 2016). Isovitexin juga dapat menghentikan perkembangan sel pada fase G2/M dan meningkatkan apoptosis (Ganesan et al., 2017). Kandungan tanin dalam ekstrak etanol daun keladi tikus juga mampu menghentikan aktivitas sel pada siklus sel fase G2/M dan meningkatkan apoptosis (Priosoeryanto et al., 2020). Adanya efek apoptosis melalui penghentian siklus sel menyebabkan penurunan tingkat mitosis sel.

Angiogenesis adalah proses pembentukan pembuluh darah baru dan merupakan proses penting pada perkembangan tumor (Priosoeryanto et al., 2020). Pembuluh darah baru yang terbentuk dapat berfungsi sebagai penyedia nutrisi, oksigen, serta jalur penyebaran tumor melalui sistem sirkulasi (Gaztelu dan Casanovas, 2018). Ekstrak etanol daun keladi tikus dapat menghambat pertumbuhan sel endotel kelinci secara in vitro dan dapat menghambat pertumbuhan pembuluh darah pada chorioallantoic membrane (CAM) (Priosoeryanto et al., 2020). Kandungan isovitexin dalam ekstrak etanol daun keladi tikus dapat menghambat HIF- $1 \alpha$ dan menurunkan gen penyandi hypoxia, karena gen ini menyandi vascular endothelial growth factor (VEGF), glyceraldehyde-3-phosphate dehydrogenase (GAPDH), collagen III, aldolase A, enolase 1, transforming growth factor beta 1 (TGF- $\alpha 1$ ), dan platelet derived growth factor á (PDGF $\alpha$ ), yang menghasilkan penurunan potensi metastasis dan penurunan angiogenesis (He et al., 2016). Tanin dalam ekstrak etanol daun keladi tikus juga dapat menurunkan terjadinya angiogenesis (Achmad et al., 2017).

\section{SIMPULAN}

Pemberian ekstrak etanol daun keladi tikus pada tumor hasil induksi DMBA secara in vivo pada mencit mampu mencegah penurunan bobot badan, menghambat pertumbuhan massa tumor, menghambat pembelahan sel (mitosis) dan menghambat pembentukan pembuluh darah (angiogenesis).

\section{SARAN}

Perlu dilakukan penelitian lanjutan dengan menggunakan tipe tumor yang berbeda secara in vivo untuk mengetahui efektivitas ekstrak etanol daun keladi tikus dalam pengobatan anti tumor.

\section{UCAPAN TERIMA KASIH}

Terima kasih penulis ucapan kepada: 1.) Ditlitabmas Kemenristekdikti atas dana penelitian melalui program Hibah Bersaing Penelitian Dasar kepada Bambang Pontjo Priosoeryanto dan Eva Harlina dengan kontrak No. 108A/KEH/SKE/X/2018; 2). Program studi Ilmu Biomedis Hewan, Divisi Patologi Departemen Klinik Reproduksi \& Patologi (KRP) Fakultas Kedokteran Hewan, Institut Pertanian Bogor; 3) Unit Hewan Laboratorium Rumah Sakit Hewan Pendidikan (RSHP) FKH Institut Pertanian Bogor; 4). Pusat Studi Biofarmaka Tropika (Trop BRC) Institut Pertanian Bogor; dan 5). Balai Penelitian Tanaman Rempah dan Obat (Balittro) Kementerian Pertanian yang telah membantu penulis sehingga penelitian ini dapat terlaksana dengan baik.

\section{DAFTAR PUSTAKA}

AVMA (American Veterinary Medical Association). 2013. Euthanasia. Journal of the American Veterinary Medical Association. 60-62.

Achmad H, Khairunnisa P, Mardiana, Auliya AK. 2017. Potentially extracted Papua's anthill(Myrmecodia pendans) as antitumor to emphasized the expression of vascular endothelial growth factor cell Burkitt's lymphoma cancer. Asian Journal of Microbiology, Biotechnology \& Environmental Sciences 20(1): 108-112.

Adnyana IK, Afifa AT, Safitri D. 2011. Aktivitas kemopreventif kanker dari ekstrak etanol temu kunci pada mencit yang diinduksi 
DMBA. Acta Pharmaceutica Indonesia 36(3): 40-43.

Ahmed I, Sozmen M. 2020. Proliferating cell nuclear antigen expression in canine and feline spontaneous and injection-site fibrosarcomas. Pakistan Veterinary Journal $1-3$.

Ahn-Jarvis JH, Parihar A, Dose AI. 2019. Dietary flavonoids for immunoregulation and cancer: Food design for targeting disease. Antioxidants 8(202): 1-30.

Arun G, Diermeier S, Akerman M, Chang, KC, Wilkinson E, Hearn S, Kim Y, MacLeod R, Krainer ADR, Norton L, Brog Li, Egeblad M, Spector DL. 2015. Differentiation of mammary tumors and reduction in metastasis upon Malat1 lncRNA loss. Genes \& Development 30: 34-51.

Baioni E, Scanziani E, Vincenti MC, Leschiera M, Bozzetta E, Pezzolato M, Desiato R, Bertolini S, Maurella C, Ru G. 2017. Estimating canine cancer incidence: findings from a population-based tumour registry in northwestern Italy. Bio Med Central Veterinary Research 13(203): 1-9.

Cardiff RD, Miller CH, Munn RJ. 2014. Manual hematoxylin and eosin staining of mouse tissue sections. Cold Spring Harbor Protocols 6: 654-658.

Cerbo AD, Palmieri B, Vico GD, Iannitti T. 2014. Onco-epidemiology of domestic animals and targeted therapeutic attempts: perspectives on human oncology. Journal of Cancer Research and Clinical Oncology 140(11): 1807-1814.

Czemplik M, Mierziak J, Szopa J, Kulma A. 2016. Flavonoid $C$-glucosides Derived from Flax Straw Extracts Reduce Human Breast Cancer Cell Growth In vitro and Induce Apoptosis. Frontiers in Pharmacology 7(282): 1-13.

Exertier P, Javerzat S, Wang B, Franco M, Herbert J, Platonova N, Winandy M, Pujol $\mathrm{N}$, Nivelles O, Ormenese S, Godard V, Becker J, Bicknell R, Pineau R, Wilting J, Bikfalvi A, Hagedorn M. 2013. Impaired angiogenesis and tumor development by inhibition of the mitotic kinesin Eg5. Oncotarget 4(12): 2302-2316.

Farida Y, Martati T, Musir A, Edward B. 2010. Uji aktivitas sitotoksik dan antioksidan dari ekstrak daun keladi tikus (Typhonium divaricatum (L) Decne). Jurnal Ilmu Kefarmasian Indonesia 8(2): 118-124.

Funk LC, Zasadil LM, Weaver BA. 2016. Living in CIN: Mitotic infidelity and its consequences for tumor promotion and suppression. Developmental Cell 39: 638652.

Ganesan K, Xu B. 2017. Molecular targets of vitexin and isovitexin in cancer therapy: a critical review. Annals of The New York Academy of Sciences 1401: 102-113.

Gaztelu IZ, Casanovas O. 2018. Unraveling the role of angiogenesis in cancer ecosystems. Frontiers in Oncology 8(248): 1-13.

Gupta K, Sood NK, Uppal SK, Mohindroo J, Mahajan S, Raghunath M, Singh K. 2012. Epidemiological studies on canine mammary tumor and its relevance for breast cancer studies. International Organization of Scientific Research Journal of Pharmacy 2(2): 102-113.

Halimah WN, Pratiwi WR, Wahyuningsih MSH. 2017. Efek kombinasi ekstrak Tithonia diversifolia (Hemsley) A.Gray dan Curcuma domestica Val terhadap nodul dan berat badan tikus model kanker. Majalah Farmaseutik 13(1): 28-37.

Hampel V, Schwarz B, Kempf C, Kostlin R, Schillinger U, Kuchenhoff H, Fenske N, Brill T, Hirschberger J. 2007. Adjuvant immunotherapy of feline fibrosarcoma with recombinant feline interferon-ù. Journal of Veterinary Internal Medicine 21: 1340 1346.

Hasanah SN, Widowati L. 2016. Jamu pada pasien tumor/kanker sebagai terapi komplementer. Jurnal Kefarmasian Indonesia 6(1): 49-59.

He M, Min JW, Kong WL, He XH, Li JX, Peng BW. 2016. A review on the pharmacological effects of vitexin and isovitexin. Fitoterapia 115: 74-85.

Jung KW, Won YJ, Kong HJ, Lee ES. 2019. Cancer statistics in Korea: incidence, mortality, survival, and prevalence in 2016. Cancer Research and Treatment 51(2): 417430.

Kim A, Ma JY. 2019. Piceatannol-3-O-â-Dglucopyranoside (PG) exhibits in vitro anti- 
metastatic and anti-angiogenic activities in HT1080 malignant fibrosarcoma cells. Phytomedicine 57: 95-104.

Kusnul Z, Suryono, Tamsuri A. 2019. Ekstrak propolis memperbaiki profil berat badan tikus model kanker payudara yang diinduksi dengan 7,12-dymethyilbenz(a) antracene (DMBA). Media Litbangkes 29(2): 135-142.

Latifah SRN. 2017. Hubungan stadium klinis dengan derajat diferensiasi sel pada pasien karsinoma sel skuamosa serviks uteri di RSUD. Abdul Moeloek Bandar Lampung. Jurnal Ilmu Kedokteran dan Kesehatan 4(4): 1-8.

Marischa S, Anggraini DI, Putri GT. 2017. Malnutrisi pada pasien kanker. Medula 7(4): 107-111.

Martano M, Lussich S, Morello E, Buracco P. 2018. Canine oral fibrosarcoma: changes in prognosis over the last 30 years. The Veterinary Journal 241: 1-7.

Mirzaiian E, Ghods ZST, Tavangar SM, Emami B, Oraei M, Safyari R, Saffar H. 2020. Utility of PHH3 in the evaluation of mitotic index in breast carcinoma and impact on tumor grade. Asian Pacific Journal of Cancer Prevention 21(1): 63-66.

Mohana N, Sivaseelan S, Amritha V, Madheswaran R, Arulmozhi A, Balasubramaniam GA. 2016. Anaplastic Vaginal Fibrosarcoma in a Cow. Indian Veterinary Journal 93(11): 46-48.

Muti'ah R, Griana TP, Ula QN, Andhyarto Y. 2016. The effect of Calotropis gigantea leaves extract on fibrosarcoma growth and caspase 3 expressions. International Journal of Pharmaceutical and Clinical Research 8(3): 167-171.

Nugroho AW. 2017. Review: konservasi keanekaragaman hayati melalui tanaman obat dalam hutan di Ondonesia dengan teknologi farmasi: potensi dan tantangan. Jurnal Sains dan Kesehatan 1(7): $377-$ 383.

Oishi N, Kondo T, Ebina A, Sato Y, Akaishi J, Hino R, Yamamoto N, Mochizuki K, Nakazawa T, Yokomichi H, Ito K, Ishikawa Y, Katoh R. 2017. Molecular alterations of coexisting thyroid papillary carcinoma and anaplastic carcinoma: identification of TERT mutation as an independent risk factor for transformation. Modern Pathology 30: 1527-1537.

Priosoeryanto BP. 2014. Penyakit Tumor pada Hewan: Biologi dan Upaya Penanganannya. Orasi Ilmiah Guru Besar IPB. Bogor. Fakultas Kedokteran Hewan IPB. IPB Press.

Priosoeryanto BP, Rostantinata R, Harlina E, Nurcholis W, Ridho R, Sutardi LN. 2020. In vitro antiproliferation activity of Typhonium flagelliforme leaves etanol extract and its combination with canine interferons on several tumor-derived cell lines. Veterinary World: 13(15): 931-939.

Purwaningsih E, Suciati Y, Widayanti E. 2016. Typhonium flagelliforme decreases telomerase expression in HeLa cervical cancer cells. Universa Medicana 35(1): 3-9.

Puspitasari E, Agustina B, Nuri, Ulfa EU. 2015. Aktivitas sitotoksik ekstrak n-heksana, diklorometana, dan metanol daun beluntas (Pluchea indica Less.) terhadap sel kanker leher rahim (HeLa). Journal of Pharmaceutical Science and Pharmacy Practice 2 (1): 41-45.

Rachmawati AS. 2020. Prevalensi kanker di rumah sakit jasa kartini kota Tasikmalaya tahun 2018. Jurnal Kesehatan Komunitas Indonesia 16(1): 119-126.

Rintelen K, Arida E, Häuser C. 2017. A review of biodiversity-related issues and challenges in megadiverse Indonesia and other Southeast Asian countries. Research Ideas and Outcomes 3: 1-16.

Setiawati A, Immanuel H, Utami MT. 2016. The inhibition of Typhonium flagelliforme Lodd. Blume leaf extract on COX-2 expression of WiDr colon cancer cells. Asian Pacific Journal of Tropical Biomedicine 6(3): 251255.

Slamet A, Andarias SH. 2018. Studi etnobotani dan identifikasi tumbuhan berkhasiat obat masyarakat sub etnis Wolio Kota Baubau Sulawesi Tenggara. Pro-Biology Education Conference 15(1): 721-732.

Sianipar NF, Ariandana, Maarisit W. 2015. Detection of gamma-irradiated mutant of rodent tuber (Typhonium flagelliforme 
Lodd.) in vitro culture by RAPD molecular marker. Procedia Chemistry 14: 285-294.

Sianipar NF, Purnamaningsih R, Rosaria. 2016. Pengembangan tanaman keladi tikus (Typhonium Flagelliforme Lodd.) asal Indonesia sebagai obat antikanker. Jurnal Penelitian dan Pengabdian Masyarakat 4 (1): 65-74.

Singh J. 2014. Histopathology of oral squamous cell carcinoma. TMU Journal of Dentistry 1(4): 141-144.

Singh P, Kumar V, Singh G, Singh A, Singh A. 2019. Significance of the apoptotic index, mitotic index, and turnover index in premalignant and malignant squamous cell lesion of the oral cavity: How much is their diagnostic and prognostic role. Journal of the Scientific Society: 46(2): 49-52.

Sukardi. 2011. Identifikasi dan karakterisasi umbi keladi tikus sebagai zat antioksidan alami. Gamma 6(2): 143-151.

Syafruddin, Suriani, Nahdawati, Sesilia Rante Pakadang SR. 2018. Pengaruh ekstrak daun keladi tikus (Typhonium flagelliforme) terhadap aktivitas antimutagenik pada mencit (Mus musculus) dengan menggunakan metode mikronukleus assay. Media Farmasi 14-(1): 35-44.

Tyagi N, Tyagi R. 2013. Squamous cell carcinoma (well-differentiated): a case report. Journal of Dentistry Oral Hygiene 5(4): $31-34$
Ullah E, Nagi AH, Ashraf M. 2013. Angiogenesis and mast cell density as predictors of patient survival in squamous cell carcinoma of the lung. Journal of Cancer Research and Therapeutic 9(4): 701-705.

Veta M, Diest PJ, Jiwa M, Al-Janabi S, Pluim JPW. 2016. Mitosis counting in breast cancer: object-level interobserver agreement and comparison to an automatic method. Plos one:11(8): 1-13.

Wimpy, Harningsih T. 2017. Uji aktivitas antioksidan kombinasi ekstrak sarangsemut (Myrmecodia pendans) dan ekstrak keladi tikus (Typhonium flagelliforme Lodd.) dengan metode dpph (1,1-Diphenyl-2-Picrilhidrazil). Jurnal Kesehatan Kusuma Husada 8-(1): 35-41.

Wulandari AD, Indrawati T, Maghfirah FF, Sari EKAP, Fauziyah S, Rosmanida. 2018. Diversity of Soil Macro Insect in Alas Purwo National Park, Banyuwangi, East Java, Indonesia. Journal of Tropical Biodiversity and Biotechnology 3: 62-66.

Zhang L, Wang S, Liu Z, Zhang L, Wang S, Wang B. 2017. Procyanidin, a kind of biological flavonoid, induces protective antitumor immunity and protects mice from lethal B16F10 challenge. International Immunopharmacology 47: 251-258.

Zheng R, Zeng H, Zhang S, Chen T, Chen W. 2016. National estimates of cancer prevalence in China, 2011. Cancer Letters 370: 33-38. 